Prosiding Seminar Nasional Teknologi Informasi dan Kedirgantaraan : Transformasi Teknologi untuk Mendukung Ketahanan Nasional, Yogyakarta, 13 Desember 2018

SENATIK 2018, Vol. IV, ISBN 978-602-52742-0-6

DOI: http://dx.doi.org/10.28989/senatik.v4i0.171

\title{
THE VISUALIZATION STUDY ON THE SLUG FLOW MECHANISMS OF THE AIR-WATER TWO-PHASE IN 50 MM HORIZONTAL PIPE
}

\author{
Okto Dinaryanto $^{1)}$, Akhmad Zidni Hudaya ${ }^{2)}$, Indarto ${ }^{3)}$, Deendarlianto ${ }^{3)}$ \\ ${ }^{1}$ Program Studi Teknik Mesin, Sekolah Tinggi Teknologi Adisutjipto \\ Jl. Janti, Blok R Lanud Adisutjipto, Yogyakarta, 55197, Indonesia. \\ ${ }^{2}$ Jurusan Teknik Mesin, Universitas Muria Kudus \\ Gondang Manis, Bae, Kudus,59324, Indonesia. \\ ${ }^{3}$ Jurusan Teknik Mesin dan Industri, Universitas Gadjah Mada \\ Jl. Grafika No. 2, Yogyakarta 55281, Indonesia. \\ Email: 1oktodinaryanto@yahoo.co.id
}

\begin{abstract}
The slug flow phenomena are often encountered in various industrial applications such as petroleum, process, and power plant. The presence of slug flow should be avoided as it causes structural damage due to resonance, corrosion and pipes blast. From the view point of multiphase flow, the understanding of the slug initiation mechanism is very important in pipeline design. This research is conducted using horizontal transparent acrylic pipes with diameters of $50 \mathrm{~mm}$ with a variation on the superficial velocity of water between $0,1 \mathrm{~m} / \mathrm{s}$ and $0,77 \mathrm{~m} / \mathrm{s}$ and superficial velocity of air between $0,31 \mathrm{~m} / \mathrm{s}$ and $6,2 \mathrm{~m} / \mathrm{s}$. In the present experimental study, the slug initiation mechanisms were explained by visual observation by using high speed video cameras. As the results, the slug flow initiation mechanisms were clarified. Furthermore, the proposed of flow initiation map was introduced.
\end{abstract}

Keyword: Slug Flow, Visualization Study, Slug Flow Mechanism.

\section{Pendahuluan}

Aliran slug banyak terdapat pada berbagai aplikasi industri seperti pada sistem perpipaan, pembangkit tenaga listrik, alat penukar kalor, proses pada industri kimia, proses pengolahan minyak, reaktor nuklir, sistem refrigrasi dan tata udara, dll. Akan tetapi kehadiran aliran slug akan berakibat buruk pada kegiatan operasional dan keamanan sistem perpipaan. Oleh karena itu aliran slug banyak dihindari oleh desainer dan operator pada sistem perpipaan [1-4]

Pola aliran slug merupakan pola yang tidak stabil di mana tumbuh dan leyapnya sangatlah fluktuatif [5]. Pada aliran slug terjadi perubahan tekanan secara mendadak dan dapat merusak sistem perpipaan. Selain itu aliran slug menimbulkan dan meningkatkan kecepatan korosi [6]. Adanya slug juga akan berakibat pada produksi minyak yang menurun. Hal tersebut juga akan berakibat pada peningkatan biaya perawatan pada produksi minyak bumi. Oleh karena itu keberadaan slug perlu dikontrol dalam rangka meningkatkan nilai keekonomisan produk $[7,8]$

Mekanisme pembentukan aliran slug dari stratified secara umum menggunakan tiga pendekatan yaitu: Kelvin-Helmholtz instability, viscous long wavelength (VLW) theory, dan stabilitas slug $[1,9,10]$. Ketiga mekanisme tersebut saling melengkapi satu dengan yang lainnya dalam menjelaskan pembentukan aliran slug dan perkembangannya. Sampai saat ini mekanisme pembentukan aliran slug pada pipa horizontal belum seluruhnya disepakati keakurasianya oleh para peneliti yang dapat dilihat dari hasil penelitian yang sama dan 
berbeda. Penyebab perbedaan pendapat adalah kondisi eksperimen, model, dan nilai parameter yang digunakan untuk menganalisis mekanisme aliran slug yang ada berbeda-beda dari masing-masing peneliti sehingga menyebabkan perbedaan hasil dan kesimpulan.

Untuk mempelajari aliran slug dapat digunakan beberapa metode yaitu visual dan image processing, fluktuasi beda tekanan, konduktivitas, kapasitansi, tomografi, dll. Metode visual dan image processing yang digunakan untuk pengenalan karakteristik suatu fenomena aliran slug pada saat ini sedang berkembang. Hal ini karena adanya kelebihan metode visual dan teknik image processing yaitu sebagai metode pengukuran non-intrusive [11-14].

Berdasarkan uraian di atas dapat diambil kesimpulan bahwa teori-teori tentang mekanisme pembentukan dan karakteristik aliran slug masih terdapat keterbatasan, sehingga para peneliti masih berbeda pendapat mengenai mekanisme dan karakteristik aliran slug yang akurat. Untuk itu perlu dilakukan studi eksperimen mengenai mekanisme aliran slug secara lebih mendalam.

Berdasarkan latar belakang yang sudah dikemukakan dan rumusan masalah, maka tujuan dalam penelitian adalah menginvestigasi tentang mekanisme aliran slug pada aliran dua fasa adiabatis searah pada pipa horizontal. Untuk pengembangan ilmu pengetahuan, penelitian ini berperan dalam memberikan data penunjang tentang mekanisme aliran slug yang masih banyak diperdebatkan oleh banyak peneliti. Untuk keperluan aplikasi di industri, data dari hasil penelitian ini dapat dimanfaatkan dalam merancang sistem perpipaan aliran dua fasa yang aman, serta dapat digunakan untuk merancang alat pendeteksi dan pengendali aliran slug.

\section{Metodologi Penelitian}

Fasilitas penelitian yang digunakan berada di Laboratorium Mekanika Fluida, Departemen Teknik Mesin dan Industri, Universitas Gadjah Mada seperti yang terlihat pada Gambar 1.

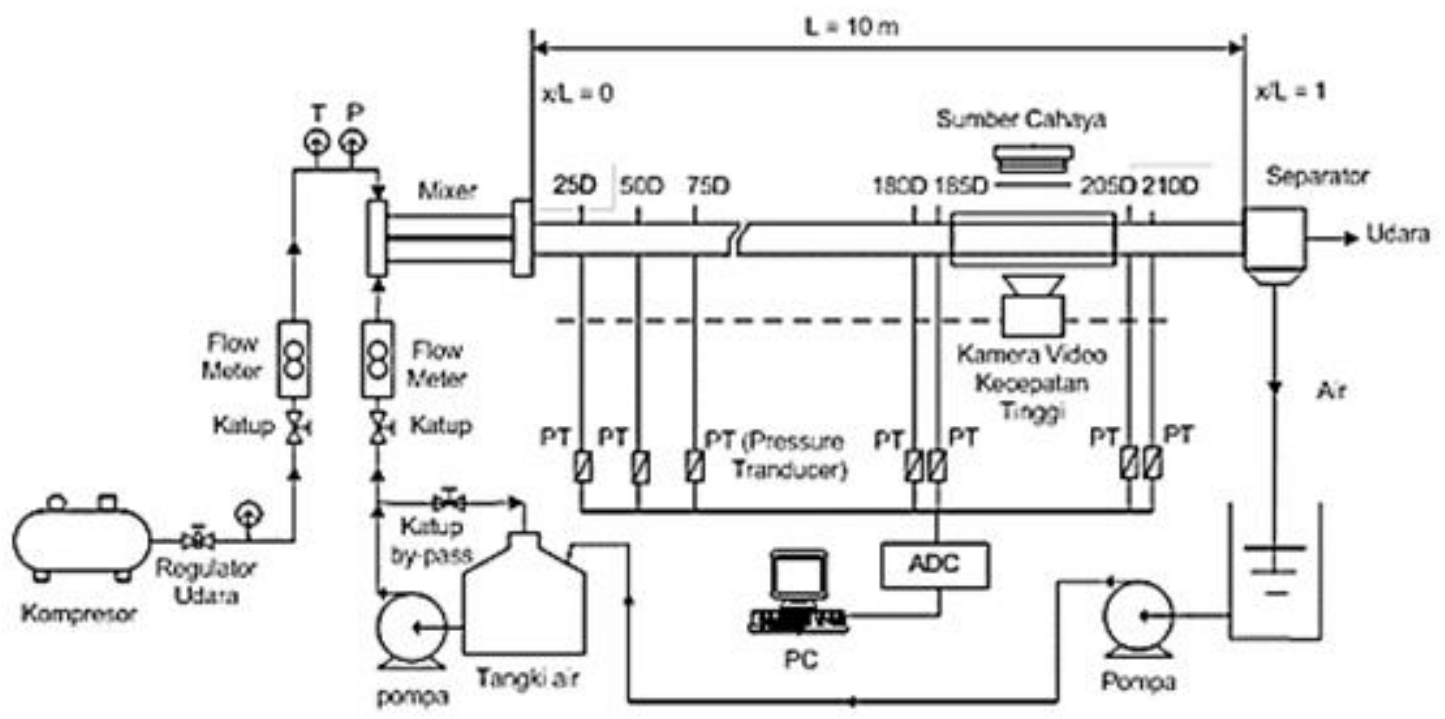

Gambar 1. Skema diagram peralatan penelitian

Pada penelitian ini digunakan pipa acrylic transparan dengan diameter dalam $50 \mathrm{~mm}$. Panjang bagian uji dirancang untuk 0 D sampai $210 \mathrm{D}$ atau sekitar untuk memastikan aliran slug berkembang dengan baik. Selain itu, panjang setelah bagian uji dirancang untuk $210 \mathrm{D}$ sampai $385 \mathrm{D}$ m untuk memastikan osilasi yang terjadi pada bagian ini tidak akan merugikan pada bagian pengujian. 
Dalam penelitian ini, percobaan dilakukan di bawah suhu kamar dimana udara dipasok dari kompresor dengan kapasitas maksimum 600 LPM dan tekanan 8 bar. Untuk mengendalikan laju alir udara digunakan dua rotary meter gas Dwyer dengan kapasitas maksimum 200 dan 600 kaki kubik/menit dengan akurasi sekitar 3\%. Untuk memasok air digunakan pompa sentrifugal, yang memiliki fluktuasi minimum dibandingkan dengan jenis pompa lainnya, dengan kapasitas $18 \mathrm{~m}^{3} / \mathrm{jam}$. Di sini, digunakan dua buah rotary meter air Omega dengan kapasitas maksimum 10 GPM dengan akurasi sekitar 2\% untuk mengendalikan laju aliran air.

Pengamatan dilakukan pada titik spesifik 25 D (Diameter), 50 D, 75 D, 100 D, 150 D, $180 \mathrm{D}$, dan $210 \mathrm{D}$ dari saluran masuk. Untuk mengamati perkembangan aliran slug di sepanjang pipa, kamera video berkecepatan tinggi dengan frame rate maksimal $1200 \mathrm{fps}$ digunakan. Kedua kamera tersebut digunakan bersamaan di area cakupan yang berbeda untuk mengamati perilaku aliran dan frekuensi slug selama 120 detik.

Penelitian dimulai dengan melakukan penginstalasian alat uji dengan pemilihan komponen sesuai dengan percobaan yang akan dilakukan. Selanjutnya dilakukan kalibrasi terhadap setiap alat ukur. Selanjutnya dilakukan pengetesan awal alat uji. Jika alat uji tersebut mencapai akurasi yang diperlukan maka dapat diteruskan pada langkah pengambilan data. Jika hasil analisis belum berkualitas maka akan diambil lagi data penelitian. Jika hasil analisis data cukup berkualitas sesuai tujuan penelitian maka dapat diambil kesimpulan. sesuai dengan tujuan penelitian.

Data penelitian dibandingkan dengan peta Mandhane [15]. Data penelitian ini meliputi daerah pola aliran slug dan transisi dari stratified ke slug. Variabel yang digunakan meliputi diameter dalam pipa dan variasi kecepatan superfisial udara dan air. Diameter dalam pipa yang digunakan adalah $50 \mathrm{~mm}$. Kecepatan superfisial air bervariasi mulai dari $0,1 \mathrm{~m} / \mathrm{s}$ sampai $0,77 \mathrm{~m} / \mathrm{s}$. Kecepatan superfisial udara mulai dari $0,31 \mathrm{~m} / \mathrm{s}$ sampai $6,2 \mathrm{~m} / \mathrm{s}$. Hasil perekaman high speed video camera yang berupa file berekstensi mov, diubah menjadi file berekstensi avi dengan program video converter.

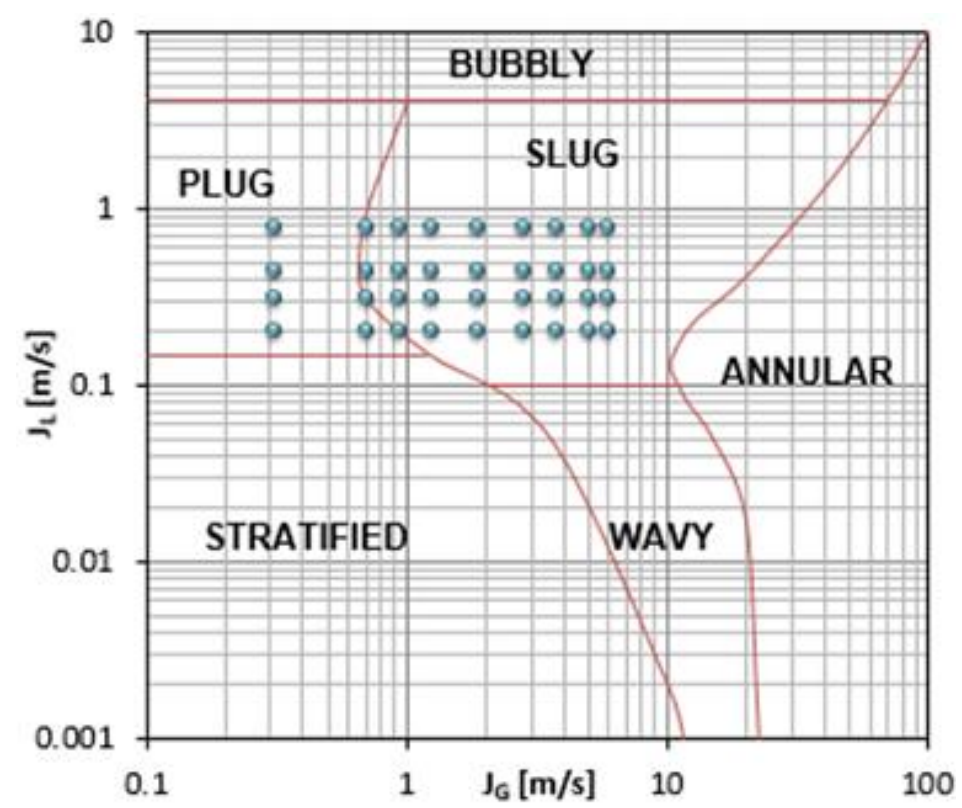

Gambar 2. Kisaran data penelitian pada peta Mandhane [15] 


\section{Hasil dan Pembahasan}

Studi visualisasi dilakukan untuk mengamati proses pembentukan dan perkembangan slug pada daerah inisisasi sampai dengan daerah berkembang penuh. Pada kecepatan superfisial air $\left(\mathrm{J}_{\mathrm{L}}\right)$ yang sangat rendah aliran berbentuk stratified. Karakteristik dari aliran stratified adalah udara mengalir pada bagian atas pipa dan air mengalir pada bagian bawah pipa dan dipisahkan oleh interface yang stabil [16]. Selanjutnya pada kecepatan superfisial air lebih tinggi $\mathrm{J}_{\mathrm{L}} \geq 0,1 \mathrm{~m} / \mathrm{s}$, aliran plug dan slug mulai terbentuk. Aliran plug terbentuk pada kecepatan superfisial udara $\left(\mathrm{J}_{\mathrm{G}}\right)$ yang relatif rendah. Pada kecepatan yang lebih tinggi $\mathrm{J}_{\mathrm{G}}=$ $2,88 \mathrm{~m} / \mathrm{s}$ (Gambar 3) terlihat terdapat titik mula kenaikan interface antara udara dan air dan diikuti dengan terbentuknya gelombang yang belum menyentuh bagian atas pipa. Gelombang yang muncul memiliki kecepatan berbeda-beda satu sama lain dan terkadang bertumbukan lalu membentuk pseudo slug $[17,18]$ atau bentuk serupa slug tetapi cairan belum secara sempurna memenuhi cross sectional pipa.

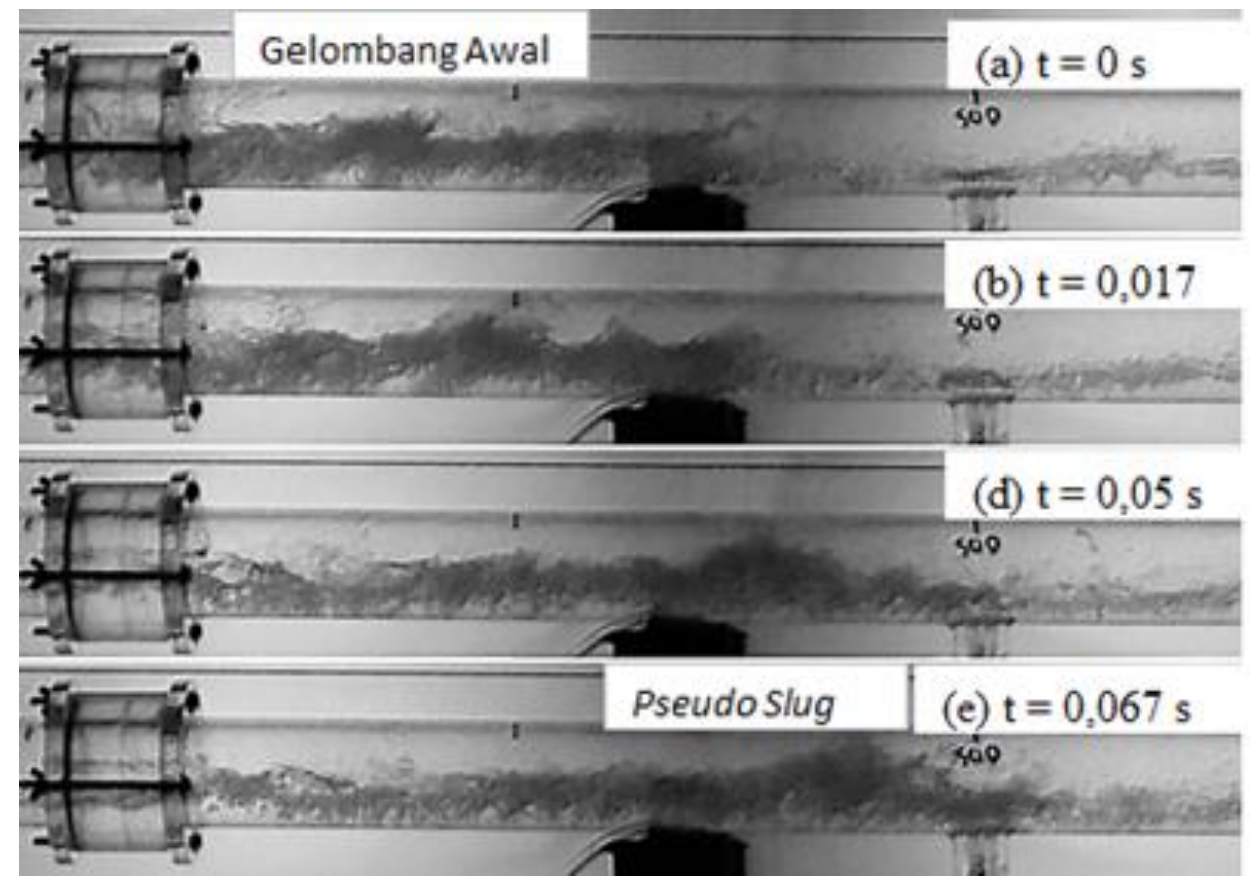

Gambar 3. Visualisasi pembentukan pseudo slug pada pipa $50 \mathrm{~mm}$ dengan $\mathrm{J}_{\mathrm{G}}=6,2 \mathrm{~m} / \mathrm{s}$ dan

$$
\mathrm{J}_{\mathrm{L}}=0,2 \mathrm{~m} / \mathrm{s} \text {. }
$$

Selanjutnya pada penambahan kecepatan superfisial air pada $J_{G}=0,31 \mathrm{~m} / \mathrm{s}$ akan menjadikan slug akan lebih mudah terbentuk. Hal ini dapat dipahami karena bertambahnya cairan akan menambah tinggi permukaan air dan menjadikan gelombang lebih mudah mencapai bagian atas pipa. Pada kecepatan kecepatan superfisial udara yang rendah yaitu JG $=1,88 \mathrm{~m} / \mathrm{s}$ mekanisme pertumbuhan gelombang (wave growth) masih dominan di mana kenaikan interface antara udara dan air dan kenaikan kecepatan udara lokal menyebabkan penurunan tekanan udara. Hal ini cenderung menyebabkan kenaikan interface antara udara dan air lebih lanjut dan menaikkan amplitudo gelombang sempai menyentuh bagian atas pipa dan menghasilkan slug seperti yang terlihat pada Gambar 4. 


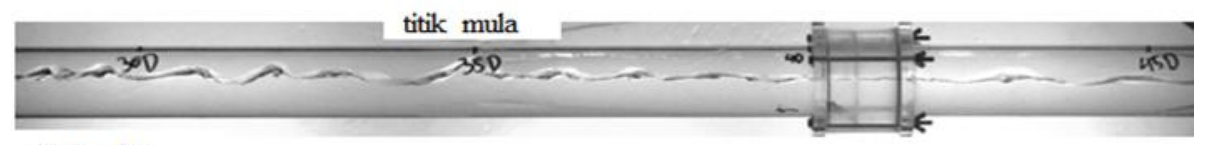

(a) $\mathrm{t}=0 \mathrm{~s}$
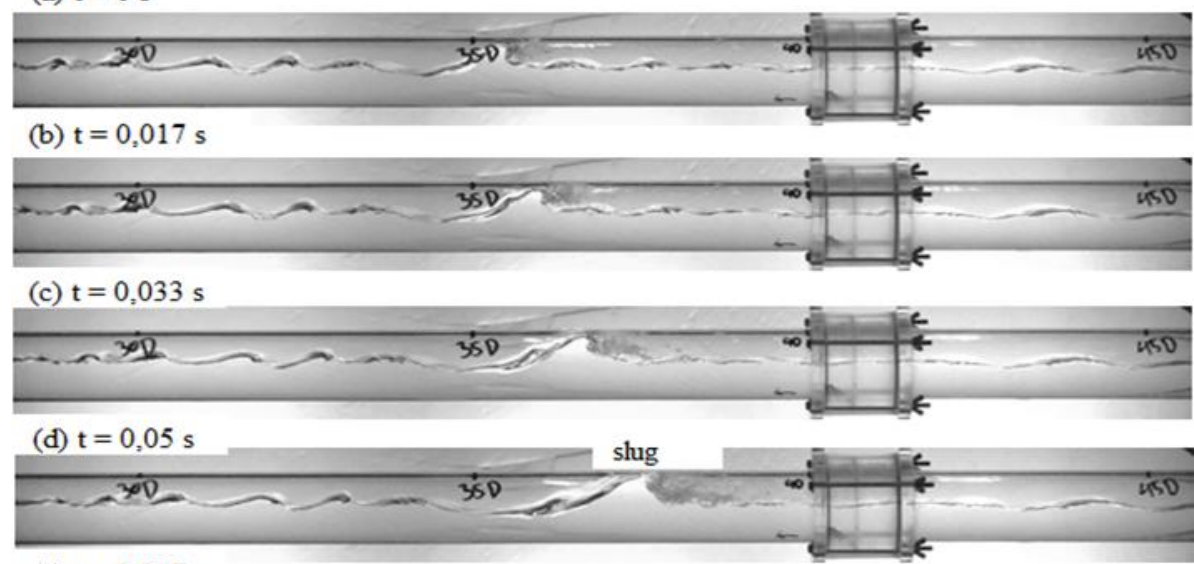

(e) $\mathrm{t}=0,067 \mathrm{~s}$

Gambar 4. Visualisasi pembentukan aliran slug pada pada pipa $50 \mathrm{~mm}$ dengan $\mathrm{JG}=1,88 \mathrm{~m} / \mathrm{s}$ dan $\mathrm{JL}=0,31 \mathrm{~m} / \mathrm{s}$.

Selanjutnya, seiring dengan meningkatnya kecepatan superfisial gas $\left(\mathrm{J}_{\mathrm{G}}<3 \mathrm{~m} / \mathrm{s}\right)$ dengan nilai kecepatan superfisial air yang konstan $\left(\mathrm{J}_{\mathrm{L}}=0,31 \mathrm{~m} / \mathrm{s}\right)$, mekanisme pembentukan slug yang terjadi mulai berbeda yaitu melalui penggabungan gelombang (wave coalescence). Air terangkat hingga area bagian atas cross-sectional pipa dan membentuk beberapa irregular wave yang mempunyai kecepatan yang berbeda. Perbedaan kecepatan ini mengakibatkan gelombang tersebut saling bertabrakan dan bergabung menjadi gelombang yang lebih besar hingga ada yang membentuk slug dengan aerated tiny bubbles di dalamnya seperti yang terlihat pada Gambar 5.

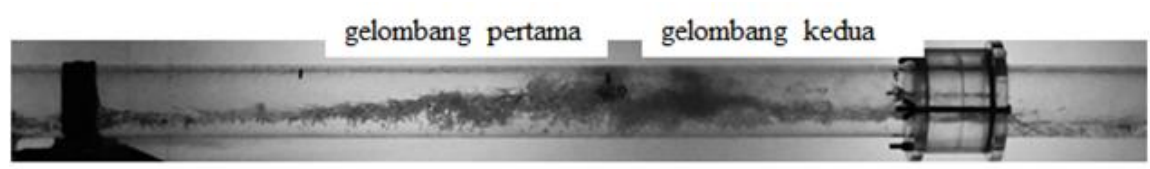

(a) $\mathrm{t}=0 \mathrm{~s}$

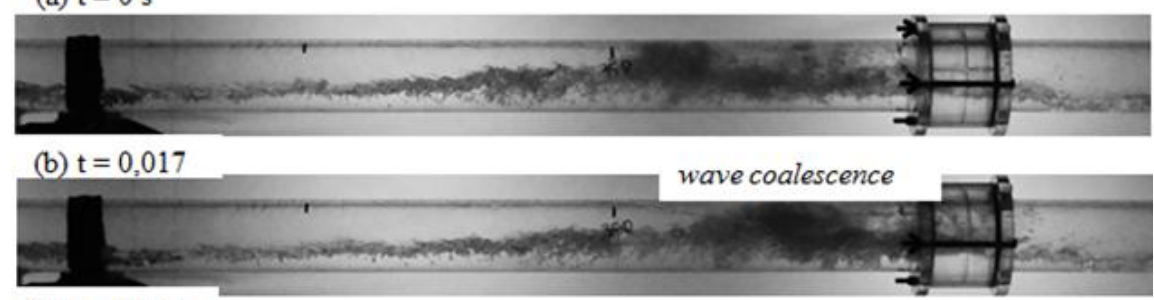

(c) $\mathrm{t}=0,033 \mathrm{~s}$

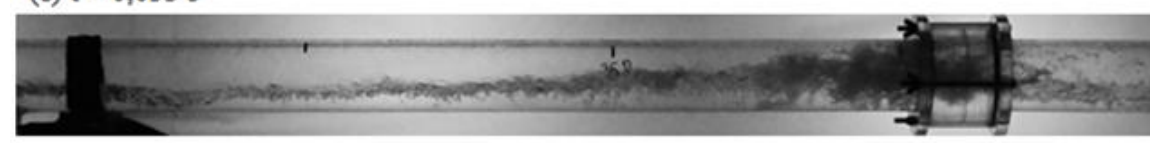

(d) $\mathrm{t}=0,05 \mathrm{~s}$

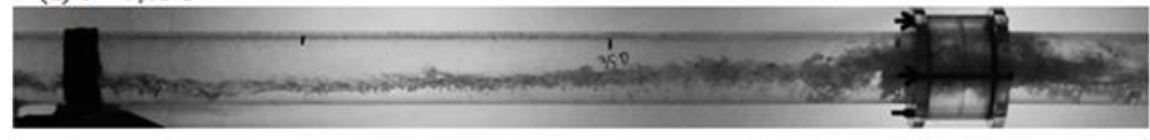

(e) $\mathrm{t}=0,067 \mathrm{~s}$

Gambar 5. Visualisasi pembentukan aliran slug pada pipa $50 \mathrm{~mm}$ dengan $\mathrm{JG}=6,2 \mathrm{~m} / \mathrm{s} \mathrm{dan} \mathrm{JL}$ $=0,31 \mathrm{~m} / \mathrm{s}$. 
Pada kecepatan superfisial air yang tinggi $\left(\mathrm{J}_{\mathrm{L}}>0,4 \mathrm{~m} / \mathrm{s}\right)$ mekanisme perkembangan gelombang tunggal maupun penggabungan gelombang tetap terjadi. Namun pada kecepatan superfisial air yang tinggi terbentuk juga gelombang gangguan (disturbance wave) pada saluran masuk yang juga mempengaruhi pembentukan slug seperti yang terlihat pada Gambar 6,7. Hal ini menjadikan slug mudah terbentuk dekat saluran masuk dan menyebabkan jumlah slug juga meningkat.
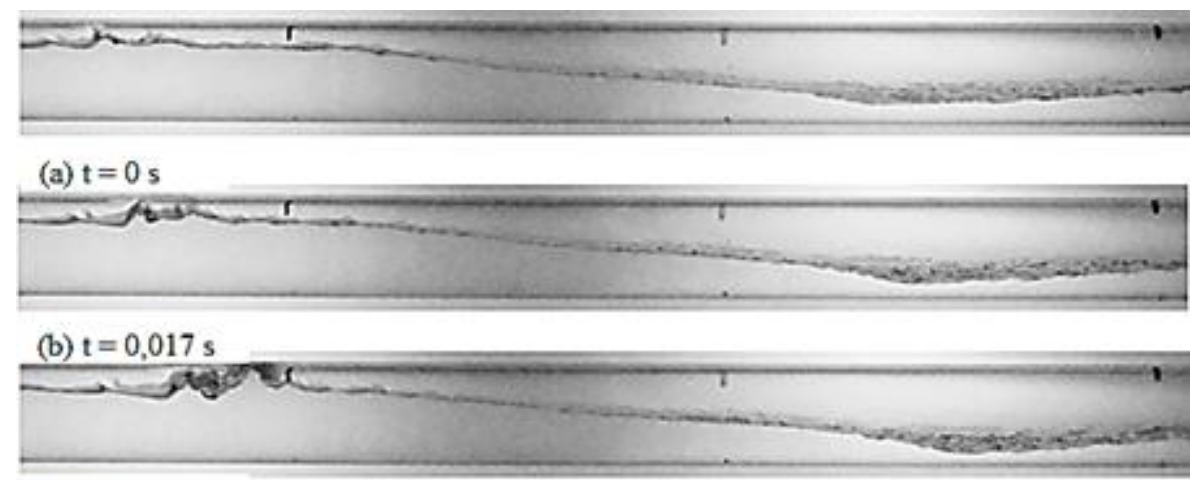

(c) $t=0,033 \mathrm{~s}$
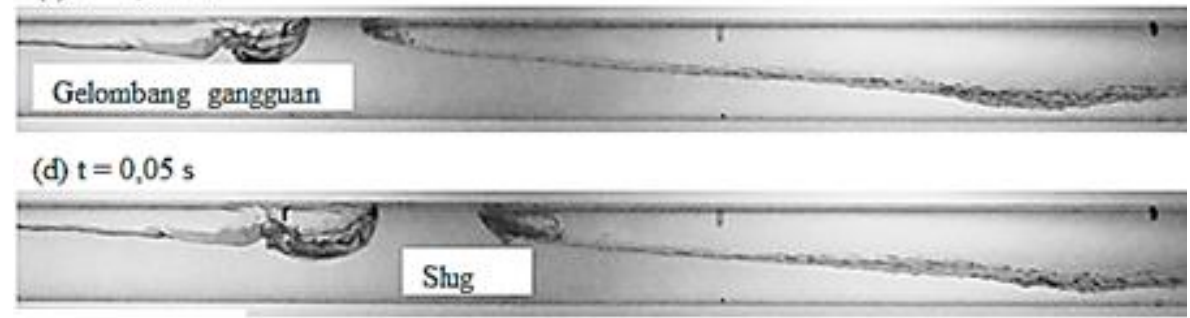

(e) $\mathrm{t}=0,067 \mathrm{~s}$

Gambar 6. Visualisasi pembentukan aliran slug pada pipa $50 \mathrm{~mm}$ dengan $\mathrm{J}_{\mathrm{G}}=1,88 \mathrm{~m} / \mathrm{s} \mathrm{dan}$ $\mathrm{J}_{\mathrm{L}}=0,77 \mathrm{~m} / \mathrm{s}$.
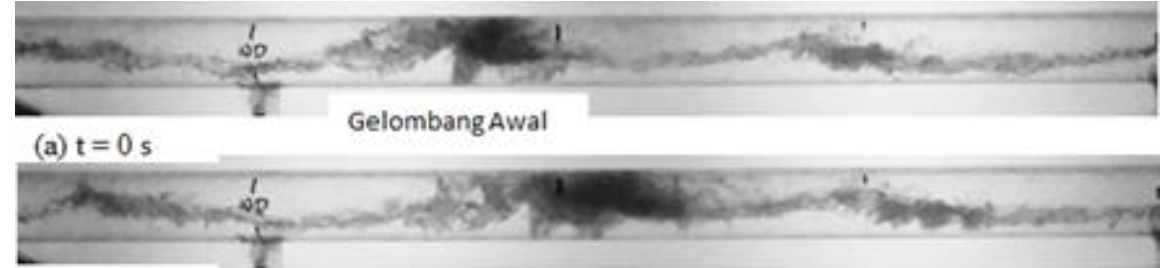

(b) $\mathrm{t}=0,017$

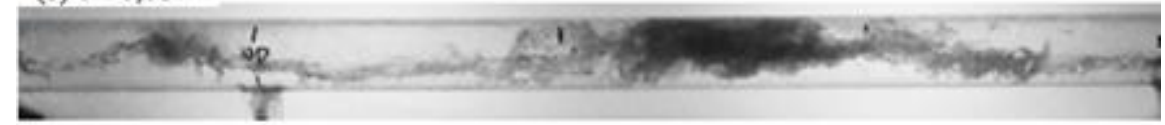

(c) $\mathrm{t}=0,033$
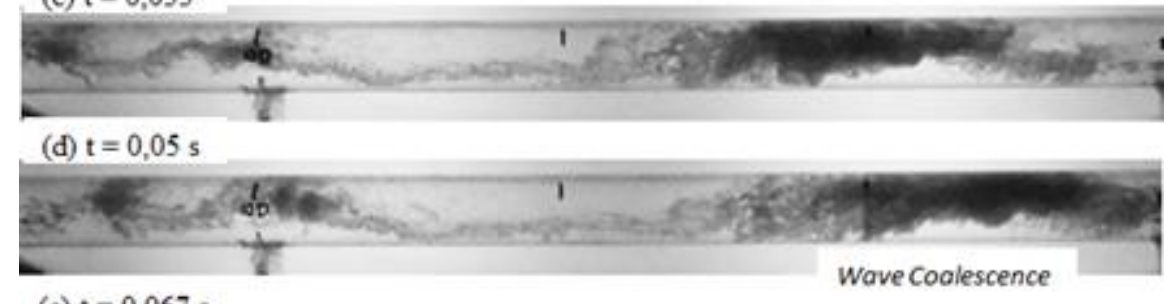

(e) $\mathrm{t}=0,067 \mathrm{~s}$

Gambar 7. Visualisasi pembentukan aliran slug pada pipa $50 \mathrm{~mm}$ dengan $\mathrm{J}_{\mathrm{G}}=6,2 \mathrm{~m} / \mathrm{s}$ dan $\mathrm{J}_{\mathrm{L}}$ $=0,77 \mathrm{~m} / \mathrm{s}$. 


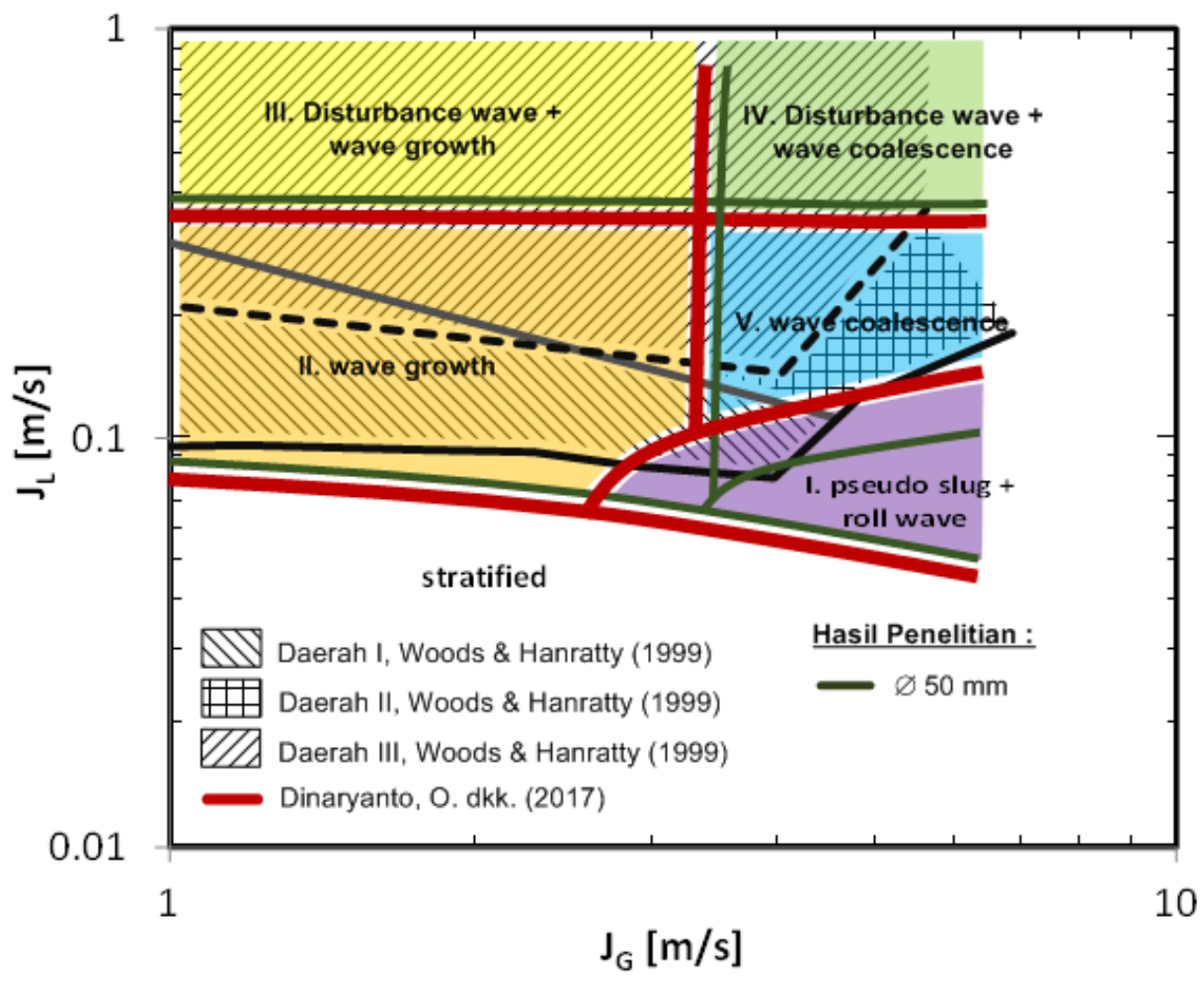

Gambar 8. Peta mekanisme inisiasi slug yang diusulkan dibandingkan dengan Dinaryanto dkk [3], Peta Wood dan Hanratty [19].

Gambar 8 menunjukkan peta yang diusulkan yang diperoleh dari pengamatan visual untuk mekanisme pembentukan aliran slug sebagai fungsi kecepatan superfisial gas dan cairan. Pada $\mathrm{J}_{\mathrm{L}}$ rendah dan $\mathrm{J}_{\mathrm{G}}$ tinggi aliran slug jarang terbentuk selama pengamatan, ditujukan sebagai Daerah I di mana hanya pseudo slug atau gelombang besar yang terbentuk. Pada peta ini terlihat untuk pipa yang lebih besar diperlukan $\mathrm{J}_{\mathrm{G}}$ yang lebih tinggi untuk membentuk pseudo slug. Untuk kecepatan superfisial gas rendah $\left(\mathrm{J}_{\mathrm{G}}<3 \mathrm{~m} / \mathrm{s}\right)$, gelombang akan tumbuh menjadi slug dengan mekanisme pertumbuhan gelombang (wave growth) ditujukan sebagai Daerah II. Pada daerah ini untuk pipa yang lebih besar diperlukan JL yang lebih tinggi agar slug dapat terbentuk. Sejalan peningkatan $\mathrm{J}_{\mathrm{L}}\left(\mathrm{J}_{\mathrm{L}}>0,4 \mathrm{~m} / \mathrm{s}\right)$ aliran slug dimulai dengan adanya kehadiran pertumbuhan gelombang dan gelombang gangguan (disturbance wave) yang ditujukan sebagai Daerah III. Di sisi lain, peningkatan kecepatan superfisial gas $\left(\mathrm{J}_{\mathrm{G}}>3 \mathrm{~m} / \mathrm{s}\right)$ yang ditujukan sebagai Daerah IV di mana aliran slug diinisiasi oleh perpaduan gelombang (wave coelesance) dan gelombang gangguan. Untuk $\mathrm{J}_{\mathrm{L}}$ menengah di daerah $\mathrm{J}_{\mathrm{G}}$ tinggi, ditujukan sebagai Daerah $\mathrm{V}$, mekanisme pembentukan aliran slug dipengaruhi oleh perpaduan gelombang.

Peta yang diusulkan kemudian dibandingkan dengan peta inisiasi dari Dinaryanto dkk. [3] pada pipa 26 terdapat kesamaan daerah-daerah inisiasi aliran slug. Namun demikian untuk batas-batas transisi antar daerah mekanisme slug nilainya sedikit berbeda di mana diperlukan $\mathrm{J}_{\mathrm{G}}$ dan $\mathrm{J}_{\mathrm{L}}$ yang lebih tinggi untuk pipa $50 \mathrm{~mm}$ untuk batas daerah transisinya. Selanjutnya dibandingkan dengan Woods \& Hanratty [19] yang membagi mekanisme menjadi 3 jenis berdasarkan bilangan Froude. Di mana di Daerah I adalah pertumbuhan gelombang, Daerah II adalah perpaduan gelombang, dan Daerah III adanya pengaruh karena gelombang ganguan dekat inlet. Meskipun ada beberapa perbedaan batas daerah antara peta tersebut, akan tetapi mekanisme inisiasi dasar dari kedua peta tersebut hampir sama atau bersesuaian. 


\section{Kesimpulan}

Studi tentang mekanisme aliran slug pada aliran dua fasa untuk fluida air dan udara dilakukan pada pipa dengan diameter $50 \mathrm{~mm}$. Kecepatan superfisial cairan dan gas serta diameter pipa memegang peranan penting dalam mekanisme inisiasi dan perkembangan serta karakteristik parameter aliran slug. Hasil penelitian dapat disimpulkan sebagai berikut:

a. Pada kecepatan superfisial air $\left(\mathrm{J}_{\mathrm{L}}\right)$ rendah dan kecepatan superfisial udara $\left(\mathrm{J}_{\mathrm{G}}\right)$ tinggi aliran slug hanya pseudo slug atau gelombang besar yang terbentuk melalui tumbukan antar roll wave.

b. Pada $\mathrm{J}_{\mathrm{L}}$ sedang pada kecepatan superfisial gas rendah $\left(\mathrm{J}_{\mathrm{G}}<3 \mathrm{~m} / \mathrm{s}\right)$, gelombang akan tumbuh menjadi slug dengan mekanisme pertumbuhan gelombang (wave growth) dan untuk $\mathrm{J}_{\mathrm{G}}$ tinggi mekanisme pembentukan aliran slug dipengaruhi oleh perpaduan gelombang (wave coalesence).

c. Pada $\mathrm{J}_{\mathrm{L}}$ tinggi $\left(\mathrm{J}_{\mathrm{L}}>0,4 \mathrm{~m} / \mathrm{s}\right)$, gelombang gangguan (disturbance wave) ikut berperan dalam pembentukan slug.

\section{Ucapan Terimakasih}

Kepada Laboratorium Mekanika Fluida, Departemen Teknik Mesin dan Industri, Universitas Gadjah Mada atas penggunaan peralatan penelitian.

\section{Daftar Pustaka}

[1] Dinaryanto, O., Hudaya, A.Z., Deendarlianto, Indarto (2015). Sifat-Sifat Aliran Slug Air-Udara Pada Pipa Horizontal Ditinjau dari Fluktuasi Beda Tekanannya. Proceeding Seminar Nasional Seminar Nasional Perkembangan Riset dan Teknologi Ke 21, UGM, Yogyakarta

[2] Dinaryanto, O., Sarworo, R. S., Majid, A.I., Indarto, Deendarlianto (2016). Studi Eksperimental Mengenai Sub-Regime Aliran Slug Dua Fasa Air-Udara pada Pipa Horizontal. Proceeding National Symposium on Thermofluids VIII, UGM, Yogyakarta

[3] Dinaryanto, O., Prayitno, Y.A.K., Hudaya, A.Z., Nusirwan, Y.A., Widyaparaga, A., Indarto, Deendarlianto (2017). Experimental investigation on the initiation and flow development of gas-liquid slug two-phase flow in a horizontal pipe. Experimental Thermal and Fluid Science, 81, 93-108.

[4] Deendarlianto, Andinusa Rahmandhika, Arif Widyatama, Okto Dinaryanto, Adhika Widyaparaga, Indarto (2019). Experimental study on the hydrodynamic behavior of gas-liquid air-water two-phase flow near the transition to slug flow in horizontal pipes. International Journal of Heat and Mass Transfer, 130, 93-108.

[5] Ujang, P.M., Lawrance, C. J., Hale, C.P., Hewitt, G.F. (2006). Slug Initiation and Evolution in Two-Phase Horizontal Flow. Int. J. Multiphase Flow, Vol. 32, pp. 527552.

[6] Villarreal, J., Laverde, D., Fuentes, C. (2006). Carbon-Steel Corrosion in Multiphase Slug Flow and CO2. Corrosion Science 48, pp. 2363-2379.

[7] Godhavn, J Fard, M.P., Fuchs, P. H., (2005). New Slug Control Strategies, Tuning Rules and Experimental Results, Journal of Process Control 15, pp. 547-557.

[8] Deendarlianto, Moeso, A., Widyaparaga, A. Dinaryanto, O., Khasani, Indarto. 2016. CFD Studies on the gas-liquid plug two-phase flow in a horizontal pipe. Journal of Petroleum Science and Engineering, 147, 779-787. 
[9] Soleimani, A. and Hanratty, T.J. (2003). Critical Liquid Flows for The Transition from The Pseudo-Slug and Stratified Patterns to Slug Flow. Int. J. Multiphase Flow, 29, 5167.

[10] Sanchis A, Johnson G. W. , Jansen A.( 2011). The Formation of Hydrodynamic Slugs by The Interaction of Waves in Gas-Liquid Two-Phase Pipe Flow. International Journal of Multiphase Flow, 37, pp. 358-368

[11] Widyatama, A., Dinaryanto, O, Indarto, Deendarlianto, (2018). The development of image processing technique to study the interfacial behavior of air-water slug twophase flow in horizontal pipes. Flow Measurement and Instrumentation, 59, 168-180.

[12] Dinaryanto, O., Widyatama, A., Majid, A. I., Deendarlianto, Indarto,(2016). Image Processing Analysis on the Air-Water Slug Two-Phase Flow in a Horizontal Pipe. AIP Conference Proceedings 1737, 040011.Kusko, A., \& Thompson, M. T. (2007). Power quality in electrical systems (Vol. 23). McGraw-Hill.

[13] Morales, R.E.M ., M. J. da Silva, E. N. Santos, L. Dorini; C. E. F. do Amaral, R. F. Alves.(2011). Image Analysis of Horizontal Two Phase Slug Flows. ASME. 54921. Volume 6: Fluids and Thermal Systems, Advances for Process Industries, pp 671-677

[14] Amaral, Do, C.E.F., Alves, R.F., da Silva M.J., Arruda, L.V.R., Dorini, L., Morales, R.E.M., Pipa, D.R. (2013). Image Processing Techniques for High-Speed Videometry in Horizontal Two-Phase Slug Flows, Flow Measurement and Instrumentation, Vol. 33, pp. 257-264.

[15] Mandhane, J.M., Gregory, G.A., Aziz, K. (1974). A flow pattern map for gas-liquid flow in horizontal and inclined pipes. International Journal of Multiphase Flow, Vol. 1, pp. 537-553.

[16] Hudaya, A.Z., Kuntoro, H. Y., Dinaryanto, O, Indarto, Deendarlianto, (2016). Experimental Investigation on the Interfacial Characteristics of Stratified Air-water Two-phase Flow in a Horizontal Pipe. AIP Conference Proceedings 1737, 040012

[17] Lin, P.Y. and Hanratty, T.J. (1987). E Effect of Pipe Diameter on Flow Patterns for Air-Water Flow in Horizontal, Int. J. Multiphase Flow, Vol. 13, No. 4 ,pp. 549-563.

[18] Humami, F., Dinaryanto, O., Hudaya, A.Z., Widyatama, A., Indarto, Deendarlianto (2018). Experimental study on the characteristics of flow pattern transitions of air-water two-phase flow in a horizontal pipe AIP Conference Proceedings 2001,030005.

[19] Woods, B.D. and Hanratty, T.J., (1996). Relation of Slug Stability to Shedding Rate. Int. J. Multiphase Flow, 22, 809-828. 